\title{
Effects of blue shrimp Litopenaeus stylirostris and goldlined rabbitfish Siganus lineatus in mono- and polyculture on production and environmental conditions
}

\author{
Luong Trung Cong ${ }^{1,2,{ }^{*} \text {, Lemonnier Hugues }}{ }^{3}$, Hochard Sebastien ${ }^{2,3}$, Royer Florence ${ }^{3}$, \\ Letourneur Yves ${ }^{2}$
}

\author{
${ }^{1}$ Nha Trang University; Nha Trang ,Vietnam \\ ${ }^{2}$ Laboratoire LIVE and LabEx "Corail”; Université de la Nouvelle-Calédonie; Nouméa Cedex, New \\ Caledonia \\ ${ }^{3}$ Lagons, Ecosystèmes et Aquaculture Durable (LEAD/NC); IFREMER; Nouméa Cedex, New \\ Caledonia \\ *Corresponding author :Trung Cong Luong, email address : trunglc@ntu.edu.vn
}

\begin{abstract}
:
This study was conducted to compare the effects of shrimp and rabbitfish in mono- and polyculture stocked at high biomass on production and environmental conditions in a mesocosm system. Shrimp $(14 \mathrm{~g})$ and/or rabbitfish $(19 \mathrm{~g})$ were stocked in four treatments with different density but with the same total biomass (236 g m-2), including shrimp monoculture (SM) (17 shrimp $\mathrm{m}-2$ ), shrimp-fish polyculture (SF) (11 shrimp and 4 rabbitfish $\mathrm{m}-2$ ), fish-shrimp polyculture (FS) (6 shrimp and 8 rabbitfish $\mathrm{m}-2$ ) and fish monoculture (FM) (12 rabbitfish $\mathrm{m}-2)$. After 10 weeks of experiment, shrimp survival and biomass were low in the treatments where shrimp were dominant (SM, SF), while rabbitfish survival and biomass were high in all the treatments. Shrimp mortality was assumed to be related to an excess of the system carrying capacity (CC). Results suggested that CC is linked to shrimp biomass/density rather than the system eutrophication level. The ecosystem became heterotrophic as daily feed supply was beyond $7 \mathrm{~g}$ m-2 per day. This threshold corresponded to the environmental CC of the semi-intensive shrimp culture system. Under these conditions, the combination of high fish biomass and low shrimp biomass appeared as the most valuable in terms of system performances.
\end{abstract}




\section{Introduction}

Aquaculture in New Caledonia is based on semi-intensive shrimp monoculture. Since several years, shrimp production performances are highly affected by seasonal mortalities due to vibriosis, both during the winter cold season (Syndrome 93) (Mermoud et al., 1998) and the warm season (Summer syndrome) (Lemonnier et al., 2006). As a consequence, the yield of the production unit is too low to reach economic sustainability. We hypothesized, as reported in several production areas in the world, that shrimp polyculture could represented a feasible method to enhance the yield of the production unit in a disease context (Martínez-Porchas et al., 2010; Tendencia et al., 2006a,b). Polyculture of shrimp and fish was found to improve shrimp growth performance due to more stable water quality (Akiyama and Angawati, 1999), increased productivity and profitability (García-Pérez et al., 2000; Tian et al., 2001; Yuan et al., 2010; Luong et al., 2014), improved utilization of supplied feed (Yuan et al., 2010; Luong et al., 2014), and minimized pollution of coastal waters caused by pond effluents (Tian et al., 2001).

However, in polyculture systems only a proper combination of ecologically different species at adequate densities will efficiently use the available resources, maximize synergism between cultured species and species-environment relationships and minimize the antagonistic ones (Milstein, 1992). Polyculture system increases production per area unit when compatibility and optimum stocking combinations are considered. Synergistic interactions among cultured species are explained on the basic of two interrelated processes: increase of food resources and improvement of environmental conditions (Milstein, 1992). It is expected that the supplied feed be consumed by both species or consumed by the main species, and the other species may feed on food in excess, feces, detritus, plankton and metabolites (Martínez-Porchas et al., 2010), which reduce undesirable wastes and improve water quality. Inversely, antagonistic interactions occur between incompatible species combinations and when the stocking rates are unbalanced (Milstein, 1992). In shrimp polyculture, it is not recommended to add species that may be attacked or devoured by the shrimp or vice versa (Martínez-Porchas et al., 2010). For example, Bell et al. (2007) reported that grow-out of Litopenaeus stylirostris with Holothuria scabra in ponds is not viable, since while high sandfish juvenile stocking density had no significant effects on shrimp, but shrimp had a significant negative effect on survival and/or growth of sandfish in sand-bottom tanks. Furthermore, all sandfish were dead or moribund after a month in a grow-out trial in ponds. Inversely, carnivorous fishes, such as Lateolabrax japonicus, Sparus macrocephalus, 
Pagrosomus major (Tian et al., 2001), Lates calcarifer, Lutjanus argentimaculatus (Tendencia et al., 2006a) can negatively affect the shrimp survival by eating them.

A previous study conducted in New Caledonia using a mesocosm system showed that Litopenaeus stylirostris and Siganus lineatus were interspecies compatible in a polyculture system. Moreover, this co-culture improved the zootechnical performances (yield, food conversion ratio) compared with shrimp monoculture without degradation of the environment in the culture system (Luong et al., 2014). However, this study was conducted at relatively low biomass in the system $\left(<300\right.$ g.m $\left.\mathrm{m}^{-2}\right)$. Benefits of this tested polyculture system could be altered by the size of the organisms and/or the density of stocking implying stressful conditions for the cultured animals (Milstein, 1992; Wang, 2007; Martínez-Porchas et al. 2010).

Thus, the present study aims to work at a total biomass compatible with the New Caledonian semi-intensive model $\left(>250\right.$ g.m $\mathrm{m}^{-2}$ ). In this context, different production models, including shrimp and fish monocultures and two combinations of shrimp-fish polyculture were tested. The goal is then to determine the zootechnical performances in relation with the system environment functioning for each treatment. These results will be necessary in order to assess carrying capacity in the different systems. To reach these objectives, we conducted a 10 weeks experiment in a mesocosm system.

\section{Materials and methods}

\subsection{Experimental system and design}

The experiment was conducted for a period of 10 weeks (mid-September to endNovember, 2013) at the Saint-Vincent Aquaculture Research Station, New Caledonia $\left(21^{\circ} 58^{\prime} \mathrm{N}, 165^{\circ} 57^{\prime} \mathrm{E}\right)$. The experiment was carried out in $16-1600 \mathrm{~L}$ outdoor circular mesocosm fibreglass tanks $\left(1.7 \mathrm{~m}^{2}\right)$. Sediment taken from an earthen shrimp pond located at the research station was mixed and spread evenly in all the tanks up to $20 \mathrm{~cm}$ (per tank). This sediment was clay-like in texture and its organic content was $1.2 \%$. Each tank was equipped with a central standpipe for water outlet and a spherical air stone with a diameter of $4 \mathrm{~cm}$ suspended $10 \mathrm{~cm}$ above the sediment surface and aeration was continuously supplied to the tank. One week before stocking, the tanks were filled with seawater, pumped from the adjacent bay, up to $75 \mathrm{~cm}$ of water level. A daily water exchange of around $10 \%$ was applied by regulating individual valves in each tank and water height was maintained at $75 \mathrm{~cm}(1275$ L in volume) above the sediment surface during the experiment. 
Shrimp and rabbitfish were randomly selected from available animals cultured for some months and stocked into the experimental tanks. Treatments were shrimp monoculture (SM), shrimp-fish polyculture (SF), fish-shrimp polyculture (FS), and rabbitfish monoculture (FM), with weights, densities and biomasses as described in Table 1.

All treatments were randomly distributed among tanks with four replicates per treatment. Cultured animals in all tanks were fed twice daily at 08:00 am and 16:00 pm with the same commercial pellet feed (35 - $40 \%$ protein, SICA Manufacturer, New Caledonia), and the same feed quantity as calculated for SM. Daily feed quantity was computed following the theoretical feeding rate used in New Caledonia shrimp farming and equivalent to $2.2-2.6 \%$ of shrimp biomass for this size class. Shrimp biomass increased during the culture period was estimated based on shrimp growth rate and survival referred from a previous study (Luong et al., 2014). Feed quantity was adjusted using feeding trays (30 cm diameter) placed in the shrimp monoculture tanks at seven day intervals. Feed consumption on the tray was closely observed to determine and adjust the feed ration (Salame,1993).

\subsection{Shrimp and rabbitfish sampling and analyses}

Before stocking, 35 shrimp and 35 rabbitfish were randomly collected and individually weighed. The data then were used to calculate shrimp and rabbitfish mean weight in order to estimate biomasses and densities for stocking. At harvesting, all shrimp and/or all rabbitfish in each tank were counted and individually weighed.

Shrimp and rabbitfish growth performances were evaluated in terms of survival rate (SR), daily weight gain (DWG), specific growth rate (SGR), final biomass and food conversion ratio (FCR). Equations used in this study to calculate each parameter were fully described in Luong et al. (2014).

\subsection{Water sampling and analyses}

Water temperature and dissolved oxygen (DO) concentrations were measured twice daily (07:30 am and 15:00 pm) in situ at mid depth in each tank using an OxyGuard meter (Handy Polaris, Birkerod, Denmark). Salinity, turbidity and $\mathrm{pH}$ were estimated twice a week (08:00 am) using conductimeter (Cond 3210, Welheim, Germany); turbidimeter (TN-100, Eutech Instruments, Singapore), and $\mathrm{pH}$ meter (pH 197i, Welheim, Germany), respectively.

Water samples (2 L) were collected every week at mid depth in each tank (08:00 am) and filtered through pre-combusted $\left(450{ }^{\circ} \mathrm{C}, 4 \mathrm{hrs}\right) \mathrm{GF} / \mathrm{C}$ Whatman fiberglass filters $(\phi: 47 \mathrm{~mm}$, 
pore size: $1.2 \mu \mathrm{m})$. Filtered water was analysed for total ammonia nitrogen $\left(\mathrm{NH}_{4}{ }^{+}-\mathrm{NH}_{3}\right)-\mathrm{N}$, (TAN) (Holmes et al., 1999), soluble reactive phosphorus (SRP) (Murphy and Riley, 1962), nitrite and nitrate nitrogen (NOx) (Wood et al., 1967), and total dissolved nitrogen (TDN) (Raimbault et al., 1999). Urea was analysed every two weeks on thawed samples according to the method developed by Mulvenna and Savidge (1992) and adapted by Goeyens et al. (1998). Dissolved organic nitrogen (DON) was expressed as the difference between TDN and total dissolved inorganic nitrogen [TAN + NOx]. To estimate chlorophyll $a(\mathrm{Chl} a)$ and phaeopigments (Phaeo), water samples of $25 \mathrm{~mL}$ were filtered through GF/F Whatman fiberglass filters $(\phi: 25 \mathrm{~mm}$; pore size: $0.7 \mu \mathrm{m})$ and then analyzed using a fluorometer (TD 700) following Holm-Hansen et al. (1965).

Total suspended solids (TSS) were estimated every two weeks in two replicates for each treatment using the method described by Aminot and Kérouel (2004).

\subsection{Sediment sampling and analyses}

Sediment samples were collected every two weeks in all tanks from $1 \mathrm{~cm}$ deep cores using $50 \mathrm{ml}$ cut-off syringes $(\phi: 2.3 \mathrm{~cm})$. The samples were collected at three different points within each tank and pooled for the analysis of organic matter content, $\mathrm{pH}$ and redox potential (Eh). Eh was estimated with a specific electrode (Consort P901, electrochemical analyzer, Beverly, MA, USA) following Hussenot and Martin (1995). pH was directly measured by pushing the glass electrode (pH 197i, Welheim, Germany) into freshly collected sediment in the sample vials. The samples then were dried at $60^{\circ} \mathrm{C}$ for one week and analyzed for loss on ignition (organic matter) in a muffle furnace at $350^{\circ} \mathrm{C}$ for $8 \mathrm{hrs}$. (Nelson and Sommers, 1996). Sediment Chl $a$ concentration was analyzed from three different samples (1 $\mathrm{cm}$ core layer) per tank. Frozen sediment samples were freeze-dried (lyophilisated) for 24 hrs., and analyzed using a TD-700 fluorometer (Holm-Hansen et al. 1965). The concentration of sediment Chl $a$ was expressed in mg. $\mathrm{m}^{-2}$. Pore water nutrient concentration was assessed at the beginning and at the end of the experiment. The samples (same sampling protocol as for OM content) were centrifuged at $2000 \mathrm{rpm}(814 \mathrm{~g}$ ) for 20 minutes. The supernatant (pore water) was used to analyze TAN and SRP following the methods described by Holmes et al. (1999) and Murphy and Riley (1962), respectively.

\subsection{Water and sediment metabolism}

Primary productivity $(\mathrm{PP})$ and respiration $(\mathrm{R})$ were estimated in the water columns and 
sediments on the day before stocking, at the early (4 days after stocking) and the late (4 days before harvesting) stages of the experiment. Those processes were estimated in two replicates per treatment and measurements were performed during two consecutive days following the oxygen concentration in light and dark bottles and benthic enclosures as described in Luong et al. (2014).

\subsection{Statistical analyses}

All data were checked for normality (Kolmogorov-Smirnov test) and homogeneity of variances (HOV, Brown Forsythe test), and statistically analyzed using one-way ANOVA (IBM SPSS software version 16.0); with possible differences among data being tested by Duncan's multiple range tests. Percent data were arcsine-transformed before statistical analyses. Statistical comparisons of experimental data among treatments were performed for overall mean values and for each time of analyses. Non-parametric test (Kruskal-Wallis test, $\mathrm{H}$ test) and Tamhane's T2 (Post-hoc, one-way ANOVA) were used when data were not normally distributed or the variances were heterogeneous. The data of TSS, and water and sediment metabolism were statistically compared among treatments using a paired Student's t-test in MS-Excel.

\section{Results}

\subsection{Shrimp and rabbitfish growth performances}

Table 1 presents the shrimp and fish stocking and harvesting data. Over the experiment, shrimp survival rates (SR) were low in SM and SF and relative high in FS. No significant difference was found between treatments due to a very variable shrimp SR in FS. Shrimp final mean weight, DWG and SGR were similar among SM, SF and FS. In SM and SF, shrimp final biomasses were significantly lower than stocking biomasses. At harvest, shrimp biomass was significantly higher in the SM than that in the FS while SF treatment did not show significant difference with the other treatments.

Rabbitfish SR was similar among treatments and ranged between 75 and $100 \%$. Rabbitfish final mean weight, DWG and SGR were comparable in all treatments. Over the experiment, rabbitfish biomass increased significantly in FS while there was no significant difference between final and stocking biomasses in SF and FM. At harvest, rabbitfish biomass was significantly lower in SF than those in FS and FM .

The combination of shrimp and rabbitfish zootechnical results led to total final biomasses were significantly higher in FM and FS than those in SM and SF. FCR was not calculated for 
SM and SF due to negative weight gain in all tanks. There was no significant difference in FCR between FM and FS.

\subsection{Water quality parameters}

Table 2 presents the water quality data. Overall mean values of temperature, dissolved oxygen (DO) concentration, salinity and $\mathrm{pH}$ were similar in all treatments over the experiment. $\mathrm{pH}$ and salinity were 7.9 and 36 respectively during the culture period. DO increased from an average of $6.2 \mathrm{mg} . \mathrm{L}^{-1}$ in the morning to around $9.0 \mathrm{mg} . \mathrm{L}^{-1}$ in the afternoon. In the first month, temperature in the morning was around $20^{\circ} \mathrm{C}$ in all treatments and gradually increased to reach $27^{\circ} \mathrm{C}$ at the end of the experiment.

Turbidity had the same temporal trend in SM, SF and FS throughout the experiment. Values rapidly increased during the first three weeks to reach more than 40 NTU (Fig. 1). Turbidity was significantly different between treatments at $\mathrm{d} 21$ with the highest values observed in SF and SM followed by FS and FM. At d28, turbidity began to decrease in SM, SF and FS to reach similar values than in FM at d35.

Chl $a$ increased during the first three weeks in all treatments to reach maximum concentrations ranging between 70 and $190 \mu \mathrm{g} . \mathrm{L}^{-1}$. However, SM and SF reached significant higher values than FS and FM at $\mathrm{d} 7$ and $\mathrm{d} 21$. From $\mathrm{d} 28$ on, no significant difference was found between treatments until the end of the experiment (Fig. 2a).

Turbidity was positively correlated with TSS $\left(\mathrm{r}^{2}=0.89, \mathrm{P}<0.01\right)$, suggesting suspended clay particles was the major source of turbidity. Chl $a$ showed a rather low but significant correlation with TSS $\left(\mathrm{r}^{2}=0.38, \mathrm{p}<0.01\right)$.

There was no significant difference in mean DON concentration among treatments. DON concentration increased from 10 to $45 \mu \mathrm{M}$ between $\mathrm{d} 0$ and $\mathrm{d} 28$ whatever the treatment. This concentration remained stable until the end of the experiment. In treatments dominated by shrimp (SM and SF), TAN concentrations rapidly increased to $16 \mu \mathrm{M}$ at $\mathrm{d} 14$. The concentrations remained high until $\mathrm{d} 49$, then to be more variable until the end of the experiment. FM showed low concentration from the beginning to d49 and gradually increased to reach $12 \mu \mathrm{M}$ at the end of the experiment. FS showed an intermediate trend. Concentration rapidly increased as observed in SM and SF in the first part of the experiment. After $\mathrm{d} 28$, the concentration became similar to FM. Mean TAN concentrations were significantly higher in SM and SF than those in FS and FM. NOx showed low concentrations ranging from 0.15 to $0.49 \mu \mathrm{M}$ in all treatments. Mean NOx concentration was significantly 
higher in FM than those in SF and FS. The temporal variations of SRP were within small ranges and the overall mean values were low in all treatments, ranged 0.2 to $0.4 \mu \mathrm{M}$.

\subsection{Sediment parameters}

Mean $\mathrm{pH}$ ranged from 7.0 to 7.3 during the experiment whatever the treatment (Table 3). Eh temporal variation showed the same trend in all treatments, which gradually decreased during the experiment from -32 to $-157 \mathrm{mV}$. Values were not significantly different between treatments whatever the date. Chl $a$ in sediment progressively increased from the beginning to the seventh week in all treatments and reached the highest values from 150 to 209 mg.m ${ }^{-2}$ (Fig. 2b).

Concerning nutrients in pore water, concentrations of initial TAN were $\sim 110 \mu \mathrm{M}$. Concentrations were higher at the end of the experiment whatever the treatment and ranged between 313 and $886 \mu \mathrm{M}$. Final values were significantly higher in SM and SF than in FS and FM (Table 3). For all the treatments, SRP in pore water remained low $(<10 \mu \mathrm{M})$ during the experiment (Table 3).

\subsection{Water and sediment metabolism}

Before stocking, GPP was nearly equivalent in the sediment and in the water column (83 \pm 25 and $67 \pm 29 \mathrm{mg} \mathrm{O} \cdot \mathrm{m}^{-2} \cdot \mathrm{h}^{-1}$, respectively) and the total ecosystem metabolism was $150 \pm$ $54 \mathrm{mg} \mathrm{O} \mathrm{O}_{2} \cdot \mathrm{m}^{-2} \cdot \mathrm{h}^{-1}$. GPP in the whole ecosystem significantly increased after stocking in all treatments reaching 430 to $834 \mathrm{mg} \mathrm{O} \cdot \mathrm{m}^{-2} \cdot \mathrm{h}^{-1}$ (Fig. 3). This trend was due to an increase of the metabolism in the water column, that dominated the whole metabolism of the ecosystem. The GPP in the whole ecosystem was not significantly different between the early and the late stages of the experiment in all treatments (Duncan comparison results were not shown in Fig. 3). At the early stage, water GPP was significantly higher in SM (818 mg O $\left.\mathrm{O}_{2} \cdot \mathrm{m}^{-2} \cdot \mathrm{h}^{-1}\right)$ than those in other treatments $\left(357-404 \mathrm{mg} \mathrm{O} \mathrm{O}_{2} \cdot \mathrm{m}^{-2} \cdot \mathrm{h}^{-1}\right)$ while sediment GPP was not significantly different among treatments $\left(16-125 \mathrm{mgO}_{2} \cdot \mathrm{m}^{-2} \cdot \mathrm{h}^{-1}\right)$. At the late stage, water GPP was not significantly different among treatments $\left(369-734 \mathrm{mg} \mathrm{O} \mathrm{O}_{2} \cdot \mathrm{m}^{-2} \cdot \mathrm{h}^{-1}\right)$ while sediment GPP was significantly higher in FM (179 $\left.\mathrm{mg} \mathrm{O}_{2} \cdot \mathrm{m}^{-2} \cdot \mathrm{h}^{-1}\right)$ than those in SM and SF treatments (39 and $29 \mathrm{mgO}_{2} \cdot \mathrm{m}^{-2} \cdot \mathrm{h}^{-1}$, respectively) (Fig. 3).

Before stocking, respiration (R) was higher in the water column than in the sediment (43 \pm 14 and $15 \pm 6 \mathrm{mg} \mathrm{O}_{2} \cdot \mathrm{m}^{-2} \cdot \mathrm{h}^{-1}$, respectively) and the total ecosystem respiration was $58 \pm 20$ $\mathrm{mg} \mathrm{O} \cdot \mathrm{m}^{-2} \cdot \mathrm{h}^{-1}$. Respiration in the water columns and in the sediments increased significantly after stocking in all treatments (Fig. 4). The entire $\mathrm{R}$ increased from the early $(\sim 180 \mathrm{mg}$ 
$\left.\mathrm{O}_{2} \cdot \mathrm{m}^{-2} \cdot \mathrm{h}^{-1}\right)$ to the late $\left(\sim 350 \mathrm{mg} \mathrm{O} \cdot \mathrm{m}^{-2} \cdot \mathrm{h}^{-1}\right)$ stage in all treatments, but the increase was significant only for monoculture systems (SM and FM) (Duncan comparison results were not shown in Fig. 4). Significant respiration differences for the sediment between the early and late stages were observed in SM, FS and FM treatments, and similarly for the water column was shown only in SM treatment. At the early stage, the entire R was significantly higher in SM than that in FM and the polyculture systems showed intermediate values not significantly different from either monoculture. The sediment showed the same trend while no difference was observed for the water column. At the late stage, The entire $\mathrm{R}$ was significantly higher in $\mathrm{SM}\left(595 \mathrm{mgO}_{2} \cdot \mathrm{m}^{-2} \cdot \mathrm{h}^{-1}\right)$ than those in the other treatments $\left(267-380 \mathrm{mg} \mathrm{O} \cdot \mathrm{m}^{-2} \cdot \mathrm{h}^{-1}\right)$ (Fig. 4). This treatment showed high respiration in the water column $\left(340 \mathrm{mg} \mathrm{O} \cdot \mathrm{m}^{-2} \cdot \mathrm{h}^{-1}\right)$ and also in the sediment (254 $\mathrm{mg} \mathrm{O} \mathrm{O}_{2} \cdot \mathrm{m}^{-2} \cdot \mathrm{h}^{-1}$ ). Concerning $\mathrm{R}$ in the sediment, FM showed high and similar value $\left(282 \mathrm{mg} \mathrm{O} \cdot \mathrm{m}^{-2} \cdot \mathrm{h}^{-1}\right)$ than $\mathrm{SM}$ but lower water respiration. In this treatment, the sediment dominated the whole respiration. SF and FS were similar and showed intermediate values of respirations for the sediment and the water column.

In the whole ecosystem, from the primary productivity and respiration in all treatments (Fig. $3 \& 4$ ), it was estimated that the trophic status (P/R) was $1.3 \pm 0.3$ before stocking. It increased to $1.5-1.9$ in SM, SF and FM treatments at the early stage and was stable in FS treatment. Values were below 1.0 in all treatments at the late stage of the experiment.

It was estimated that the $\mathrm{P} / \mathrm{R}$ in the water column increased from below 1.0 before stocking to $1.5-2.8$ at the early stage and then decreased to $1.0-2.0$ at the late stage.

In the sediment, the $\mathrm{P} / \mathrm{R}$ had a high value (2.8) before stocking. It decreased to below 1.0 in SM and FS treatments at the early stage, and was under 1.0 in all treatments at the late stage of the experiment.

\section{Discussion}

\subsection{Zootechnical performances and carrying capacity of the system}

While our experimental setup led to a similar initial biomass, and thus feed input in all the treatments, shrimp mortality increased with their stocking biomass and density. Thus, survival rates were twice lower in the SF and SM treatments (biomasses: 156 and 237 g.m ${ }^{-2}$ respectively) than in the FS treatment (biomass: $81 \mathrm{~g} . \mathrm{m}^{-2}$ ). If we hypothesize that this low survival can be interpreted as an outreach of the system carrying capacity. This implies that carrying capacity is linked to shrimp biomass/density rather than to the system eutrophication level. Indeed eutrophication indicators (phytoplankton, TDN and microphytobenthos) showed 
very similar values during the first part of the experiment (before d35). The shrimp mortality could not be monitored directly in our experimental system. As a consequence, shrimp mortality during the experiment led to a gap between theoretical biomass and the effective biomass in the tanks and thus overfeeding of the system. This may have increased stressful conditions for shrimp enhancing mortality. In the SM and SF treatments, black sludge (not shown) was developed on the bottom sediment as a result of intensive degradation of organic matter that led to reduced conditions (Muralidhar et al., 2014). Redox potential value (-102 - $117 \mathrm{mV}$ ) suggests that iron reduction $(\mathrm{Fe} 3+\rightarrow \mathrm{Fe} 2+)$ and sulfate reduction $(\mathrm{SO} 42-\rightarrow \mathrm{S} 2-)$ occurred in these sediments and toxic sulfide might have been generated in the sediments (Avnimelech and Ritvo, 2003; Muralidhar et al., 2014). Together with this, final pore water TAN was higher than the stressful level for L. stylirostris reported in shrimp ponds (Mugnier et al., 2006). The effects of anoxic conditions on TAN accumulation could have a negative impact on shrimp growth and lead to shrimp mortality (Hargreaves, 1998; Joyni et al., 2011). As a consequence, shrimp final biomasses in these treatments at the end of the experiment were very low and incompatible with the semi-intensive model $\left(>250\right.$ g.m $\left.\mathrm{m}^{-2}\right)$.

Rabbitfish high survival, growth rate and weight gain in the SF and the FS treatments indicated rabbitfish could well tolerate the environmental conditions implied by the cultured animal biomass. Contrary to shrimp, fish survival was good whatever their initial biomass. This difference of zootechnical performances between these two species led to a clear advantage of fish culture over shrimp culture in these condition. FS polyculture system showed some advantages compared to fish monoculture. Indeed this treatment showed the maximum yield and was compatible with the production objectives, but it also allowed to a diversification of the pond production. Nevertheless, fish culture seemed to reach its limit as some mortalities were observed at the end of the experiment. The reason of fish mortality $(25 \%)$ in the SF and FM treatments was unknown, but was likely related to eutrophication in the culture system. Rabbitfishes have high tolerance of a fairly wide range of changes in salinity and temperature, rough handling and crowding (Lam, 1974; Duray, 1998) and are generally capable of adapting to reduced oxygen concentration (Ben-Tuvia et al., 1973). The lower limit DO is 2 mg.L. $\mathrm{L}^{-1}$ for most rabbitfishes (Lam, 1974; Duray, 1998; Luong et al., 2014; Luong et al., 2013 unpublished data). The tolerance of rabbitfishes on other environmental factors such as ammonia, nitrite, ferrous iron, hydrogen sulfide, various organic compounds, etc. was not reported. Mortalities closely coincided with phytoplankton blooming as Chl $a$ concentrations were beyond $150 \mu \mathrm{g} . \mathrm{L}^{-1}$ (Luong et al., 2013 unpublished data). 
The floating dead rabbitfish were checked under microscope, but clinical signs that can explain the mortality were not found.

\subsection{Ecological functioning and carrying capacity}

Microbial processes are the key of decomposition of organic matter in aquaculture systems and thus control the eutrophication of ecosystem. The increases of GPP in the whole ecosystem after stocking were derived from strong development of phytoplankton as a result of increased nutrient supply into the culture tanks. This development appeared to be at the expense of sediment primary production which did not show any stimulation and even an inhibition in the SM. This might be due to reduced light quantity reaching the sediment surface and/or by the strong bioturbation inducing a degradation of the benthic biofilm and its resuspension. This resulted in a strong dominance of primary production in the water column over that in the sediment.

Water, sediment and entire GPP were not different between the early and the late stages indicating unchanged photosynthetic processes although nutrient input increased in the system. The factors responsible for primary production limitation might be both the self shading, caused by high biomass of phytoplankton and high level of resuspension, and the phosphate limitation (expressed as N/P ratio superior to 40 ). The unbalanced nitrogen to phosphate ratio compared to the Redfield ratio was more pronounced for treatments with shrimp dominance and led to TAN accumulation during the first part of the experiment. In the tanks dominated by fish biomass, TAN accumulation only appeared at the end of the experiment suggesting a better balance between the nitrogen and the phosphate cycle in this system.

Respiration in the water, sediment and whole ecosystem gradually increased in all treatments during the experiment as a result of the increased organic matter input from feed and metabolites produced by primary production. Both the water column and the sediment played an important role in organic matter recycling. Sediment respiration accounted for around 30 to $35 \%$ of the whole respiration (this study and Luong et al., 2014) and stayed stable whatever the stage of the culture and the feeding amount from 2.4 to $8.2 \mathrm{~g} . \mathrm{m}^{-2} \cdot \mathrm{d}^{-1}$. Nevertheless, the level of sediment respiration reached at the end of the experiment implied the dominance of anaerobic processes and thus the accumulation of reduced substances such as TAN. 
The trophic status of the water and the sediment varied in different ways during the experiment, which reflected an alteration of the system functioning. Indeed after stocking, the increase of the GPP in the water column led to an evolution from equilibrium $(\mathrm{P} / \mathrm{R}=1)$ to a marked autotrophy, while the sediment evolved from autotrophy to a near total heterotrophy due to the strong inhibition of its primary production. This trend was conserved to the end of the experiment even though the augmentation of respiration in the system took the water column back to value closer to the equilibrium. The consequences of those features is that the system functioned based on a strong benthic pelagic coupling, water column autotrophy fuelling (feed) the benthic heterotrophic metabolism. In this scheme of functioning, the sediment should have produced important nutrient fluxes back to the water column, sustaining its primary production (Herbert, 1999). From a whole system perspective, there was an evolution to heterotrophy which implies that the microbial loop depended on the allochthonous organic input to maintain its metabolism. This also means that the oxygen budget of the system is negative at the day scale.

Using results from Luong et al. (2014) and this study, we noticed that the ecosystem became heterotrophic as daily feed supplied to the tanks was beyond $7 \mathrm{~g} \cdot \mathrm{m}^{-2} \cdot \mathrm{d}^{-1}$ near the end of the culture period (Fig. 5). This threshold corresponded to the environmental carrying capacity of the semi-intensive culture system. Pore water TAN accumulating, sediment oxygen demand (SOD) increasing and GPP decreasing, and concomitantly cultured animal mortality were observed in the system. When the ecosystem became heterotrophic, SOD increased while total GPP decreased, leading to depletion of oxygen produced by metabolic processes. Under these conditions, the rabbitfish-shrimp polyculture was likely of great advantage to production performances.

To avoid degraded environmental conditions, the results susgest that the feed amount should not exceed $7 \mathrm{~g} \cdot \mathrm{m}^{-2} \cdot \mathrm{d}^{-1}$. However, this could limit production and further intensification of aquaculture systems. In aquaculture, feed and oxygen must be supplied and metabolic waste products must be removed (Stigebrandt, 2011). To cope with the environmental shift, the production model have to alter to adopt the structure and protocol of intensive farming, such as intensive aeration, high water exchange rate, and pond bottom sediment management (Boyd et al., 2002; Avnimelech and Ritvo, 2003). This view is supported by studies in the intensive and semi-intensive systems which report that in these systems more oxygen is consumed than provided through photosynthesis and surface diffusion, hence aeration is needed (Torres-Beristain, 2005). 


\section{Acknowledgements}

We are very grateful to the laboratory technical staff at IFREMER, IRD (LAMA) and New Caledonia University for their help in sample analysis. This study was supported by grant from the South Province of New Caledonia and carried out at the IFREMER SaintVincent Aquaculture Research Station and the New Caledonia University.

\section{References}

Akiyama, D.M., Angawati, A.M., 1999. Polyculture of shrimp and tilapia in East Java. American soybean Association (ASA), Technical Bulletin AQ, 47 pp.

Aminot, A., Kérouel, R., 2004. Hydrologie des écosystèmes marins. Paramètres et analyses. E.d. Ifremer, 336p.

Avnimelech, Y., Ritvo, G., 2003. Shrimp and fish pond soils: processes and management. Aquaculture 220, $549-567$.

Bell, J.D., Agudo, N.N., Purcell, S.W., Blazer, P., Simutoga, M., Pham, D., Delle Patrona, L., 2007. Growth-out of sandfish Holothuria scabra in ponds shows that co-culture with shrimp Litopenaeus stylirostris in not viable. Aquaculture 273, 509 - 519.

Ben-Tuvia, A., Kissil, G.Wm., Popper, D., 1973. Experiments in rearing rabbitfish (Siganus rivulatus) in sea water. Aquaculture 1, 359-364.

Boyd, C.E., Wood, C.W., Thunjai, T., 2002. Aquaculture pond bottom soil quality management. Pond Dynamics/Aquaculture Collaborative Research Support Program Oregon State University, Corvallis, Oregon 97331 - 1641, 41 pp.

Duray, M.N., and Southeast Asian Fisheries Development Center, 1998. Biology and culture of siganids. (Rev. ed.). Tigbauan, Iloilo, Philippines: Aquaculture Department, Southeast Asian Fisheries Development Center.

García-Pérez, A., Alston, D.E., Cortés-Maldonado, R., 2000. Growth, survival, yield, and size distributions of freshwater prawn Macrobrachium rosenbergii and tilapia Oreochromis niloticus in polyculture and monoculture system in Puerto Rico. Journal of the World Aquaculture Society 31 (3), 446 - 451. 
Goeyens, L., Kindermans, N., Abu Yusuf, M., Elskens, M., 1998. A room temperature procedure for the manual determination of urea in seawater. Estuarine, Coastal and Shelf Science $47,415-418$.

Hargreaves, J.A., 1998. Nitrogen biogeochemistry of aquaculture ponds. Aquaculture 166, $181-212$.

Herbert, R.A., 1999. Nitrogen cycling in coastal marine ecosystems. FEMS Microbiology Reviews, 23:563-590.

Holmes, R.M., Aminot, A., Kérouel, R., Hooker, B.A., Peterson, B.J., 1999. A simple and precise method for measuring ammonium in marine and freshwater ecosystems. Canadian Journal of Fisheries and Aquatic Sciences 56, 1801 - 1808.

Holm-Hansen, O., Lorenzen, C.J., Holms, P.E., Strickland, J.D.H., 1965. Fluorometric determination of chlorophyll. Journal du conseil International pour l'exploitation de la mer $30,3-15$.

Hussenot, J., Martin, J.L.M., 1995. Assessment of the quality of pond sediment in aquaculture using simple rapid techniques. Aquaculture International 3, 123 - 133.

Joyni, M.J., Kurup, B.M., Avnimelech, Y., 2011. Bioturbation as a possible means for increasing production and improving pond soil characteristics in shrimp-fish brackish water ponds. Aquaculture 318, $464-470$.

Lam, T.J., 1974. Siganids: their biology and mariculture potential. Aquaculture 3, 325 - 354 .

Lemonnier, H., Herbland, A., Salery, L., Soulard, B., 2006. "Summer syndrome" in Litopenaeus stylirostris grow out ponds in New Caledonia: Zootechnical and environmental factors. Aquaculture, 261, 1039-1047.

Luong, T.C., Hochard, S., Royer, F., Lemonnier, H., Letourneur, Y., 2014. Feasibility of polyculture of blue shrimp Litopenaeus stylirostris and goldlined rabbitfish Siganus lineatus in a mesocosm system. Aquaculture 433, 340 - 347.

Martínez-Porchas, M., Martínez-Córdova, L.R., Porchas-Cornejo, M.A. and López-Elías, J.A., 2010. Shrimp polyculture: a potentially profitable, sustainable, but uncommon aquacultural practice. Reviews in Aquaculture 2, $73-85$.

Mermoud, I., Costa, R., Ferré, O., Goarant, C., Haffner, P., 1998. "Syndrome 93" in New Caledonia outdoor rearing ponds of Penaeus stylirostris: history and description of three major outbreaks. Aquaculture, 164, 323-335. 
Milstein, A., 1992. Ecological aspects of fish species interactions in polyculture ponds. Hydrobiologia 231, $177-186$.

Mugnier, C., Lemonnier, H., Legrand, A., 2006. Physiological response of the blue shrimp Litopenaeus stylirostris to short-term confinement on a pond bottom. Aquaculture 253, 703-711.

Mulvenna, P.F., Savidge, G., 1992. A modified manual method for the determination of urea in seawater using diacetylmonoxime reagent. Estuarine, Coastal and Shelf Science 34, $429-438$.

Muralidhar, M., Saraswathy, R., Lalitha, N., Kumararaja, P., Poniah, A.G., 2014. Redox potential as an indicator of pond bottom sediment condition. Central Institute of Brackishwater Aquaculture (Indian Coucil of Agricultural Research). CIBA e-publication Series No. 26, 6pp.

Murphy, J., Riley, JP., 1962. A single solution method for the determination of soluble phosphate in sea water. Journal of the Marine Biology Association of the United Kingdom 37, $9-14$.

Nelson, D.W., Sommers, L.E., 1996. Total carbon, organic carbon, and organic matter. In: Methods of Soil Analysis. Part 2, $2^{\text {nd }}$ ed., Page A.L., et al., Ed. Agronomy 9: 961 - 1010. America Society of Agronomy, Inc., Madison, Wisconsin, USA.

Raimbault, P., Pouvesle, W., Diaz, F., Garcia, N., Sempéré, R., 1999. Wet-oxidation and automated colorimetry for simultaneous determination of organic carbon, nitrogen and phosphorus dissolved in sea water. Marine Chemistry 66, $161-169$.

Salame, M., 1993. Feeding trays in penaeid shrimp ponds. Aquac. Mag. 19 (4), 59-63.

Stigebrandt, A., 2011. Carrying capacity: general principles of model construction. Aquaculture Research 42, $41-50$.

Tendencia, E.A., dela Pena, M.R., Choresca Jr, C.H., 2006a. Presence of snapper, seabass, and siganid inhibits growth of luminous bacteria in a simulated shrimp culture system. Aquaculture 260, $54-60$.

Tendencia, E.A., Fermin, A.C., dela Peña, M.R., Choresca, J.C.H., 2006b. Effect of Epinephelus coioides, Chanos chanos, and GIFT tilapia in polyculture with Penaeus monodon on the growth of the luminous bacteria Vibrio harveyi. Aquaculture, 253, 48-56.

Tian, X., Li, D., Dong, S., Yan, X., Qi, Z., Liu, G., Lu, J., 2001. An experimental study on closed-polyculture of penaeid shrimp with tilapia and constricted tagelus. Aquaculture $202,57-71$. 
Torres-Beristain, B., 2005. Organic matter decomposition in simulated aquaculture ponds. $\mathrm{PhD}$ thesis, Fish Culture and Fisheries Group, Wageningen Institute of Animal Sciences. Wageningen university, P.O. Box 338, 6700 AH Wageningen, The Netherlands.

Wang, J-Q., Li, D., Dong, S., Wang, K., Tian, X., 1998. Experimental studies on polyculture in closed shrimp ponds: I. Intensive polyculture of Chinese shrimp (Penaeus chinesis) with tilapia hybrids. Aquaculture 163, $11-27$.

Wood, E.D., Armstrong, F.A.J., Richards F.A., 1967. Determination of nitrate in sea water by cadmium copper reduction to nitrite. Journal of the Marine Biological Association of the United Kingdom 47, 23 - 31.

Yuan, D., Yi, Y., Yakupitiyage, A., Firzimmons, K., Diana, J.S., 2010. Effects of addition of red tilapia (Oreochromis spp.) at different densities and sizes on production, water quality and nutrient recovery of intensive culture of white shrimp (Litopenaeus vannamei) in cement tanks. Aquaculture 298, 226 - 238. 
Table 1: Stocking and harvesting parameters of blue shrimp and goldlined rabbitfish for monoculture and polyculture treatments. Values are means \pm SD.

\begin{tabular}{|c|c|c|c|c|}
\hline \multirow[b]{2}{*}{ Performance } & \multicolumn{4}{|c|}{ Treatment } \\
\hline & $\begin{array}{c}\text { Shrimp } \\
\text { monoculture }\end{array}$ & $\begin{array}{l}\text { Shrimp-fish } \\
\text { polyculture }\end{array}$ & $\begin{array}{l}\text { Fish-shrimp } \\
\text { polyculture }\end{array}$ & $\begin{array}{l}\text { Rabbitfish } \\
\text { monoculture }\end{array}$ \\
\hline \multicolumn{5}{|l|}{ Stocking } \\
\hline \multicolumn{5}{|l|}{ Shrimp } \\
\hline Density (shrimp.m ${ }^{-2}$ ) & $17 \pm 0$ & $11 \pm 0$ & $6 \pm 0$ & \\
\hline Mean weight (g.shrimp. ${ }^{-1}$ ) & $13.9 \pm 0.2^{\mathrm{a}}$ & $13.9 \pm 0.3^{\mathrm{a}}$ & $13.7 \pm 0.6^{\mathrm{a}}$ & \\
\hline Biomass $\left(\mathrm{g} \cdot \mathrm{m}^{-2}\right)$ & $237 \pm 3.0^{\mathrm{a}}$ & $156 \pm 3.9^{\mathrm{b}}$ & $81 \pm 3.5^{\mathrm{c}}$ & \\
\hline \multicolumn{5}{|l|}{ Fish } \\
\hline Density (fish.m ${ }^{-2}$ ) & & $4 \pm 0$ & $8 \pm 0$ & $12 \pm 0$ \\
\hline Mean weight (g.fish ${ }^{-1}$ ) & & $19.5 \pm 0.6^{\mathrm{a}}$ & $18.8 \pm 0.3^{\mathrm{a}}$ & $19.0 \pm 0.1^{\mathrm{a}}$ \\
\hline $\operatorname{Biomass}\left(\mathrm{g} \cdot \mathrm{m}^{-2}\right)$ & & $80 \pm 2.3^{\mathrm{a}}$ & $155 \pm 2.1^{\mathrm{b}}$ & $235 \pm 1.6^{\mathrm{c}}$ \\
\hline Combined biomass $\left(\mathrm{g} \cdot \mathrm{m}^{-2}\right)$ & $237 \pm 3.0^{\mathrm{a}}$ & $236 \pm 4.5^{\mathrm{a}}$ & $236 \pm 5^{a}$ & $235 \pm 1.6^{\mathrm{a}}$ \\
\hline \multicolumn{5}{|l|}{ Harvesting } \\
\hline \multicolumn{5}{|l|}{ Shrimp } \\
\hline Density (shrimp.m ${ }^{-2}$ ) & $5.6 \pm 1.6$ & $4.1 \pm 1.1$ & $3.7 \pm 1.9$ & \\
\hline $\mathrm{SR}(\%)$ & $32.8 \pm 9.1^{\mathrm{a}}$ & $36.8 \pm 9.6^{\mathrm{a}}$ & $62.5 \pm 32.0^{\mathrm{a}}$ & \\
\hline Mean weight (g.shrimp ${ }^{-1}$ ) & $21.1 \pm 1.3^{\mathrm{a}}$ & $19.9 \pm 3.5^{\mathrm{a}}$ & $19.2 \pm 1.1^{\mathrm{a}}$ & \\
\hline DWG $\left(g \cdot d^{-1}\right)$ & $0.10 \pm 0.02^{\mathrm{a}}$ & $0.09 \pm 0.05^{\mathrm{a}}$ & $0.08 \pm 0.01^{\mathrm{a}}$ & \\
\hline $\operatorname{SGR}\left(\% \cdot d^{-1}\right)$ & $0.6 \pm 0.1^{\mathrm{a}}$ & $0.5 \pm 0.2^{\mathrm{a}}$ & $0.5 \pm 0.1^{\mathrm{a}}$ & \\
\hline Final biomass (g.m²) & $116.4 \pm 26.4^{\mathrm{a}}$ & $81.6 \pm 23.1^{\mathrm{ab}}$ & $69.5 \pm 33.7^{\mathrm{b}}$ & \\
\hline \multicolumn{5}{|l|}{ Fish } \\
\hline Density (fish.m ${ }^{-2}$ ) & & $3.1 \pm 0.9$ & $8.0 \pm 0.0$ & $9.4 \pm 4.8$ \\
\hline $\mathrm{SR}(\%)$ & & $75.0 \pm 21.4^{\mathrm{a}}$ & $100.0 \pm 0.0^{\mathrm{a}}$ & $76.2 \pm 38.7^{\mathrm{a}}$ \\
\hline Mean weight (g.fish. ${ }^{-1}$ ) & & $47.3 \pm 9.1^{\mathrm{a}}$ & $47.3 \pm 4.9^{\mathrm{a}}$ & $42.7 \pm 5.3^{\mathrm{a}}$ \\
\hline DWG $\left(g . d^{-1}\right)$ & & $0.40 \pm 0.13^{\mathrm{a}}$ & $0.41 \pm 0.07^{\mathrm{a}}$ & $0.38 \pm 0.03^{\mathrm{a}}$ \\
\hline $\operatorname{SGR}\left(\% \cdot d^{-1}\right)$ & & $1.26 \pm 0.31^{\mathrm{a}}$ & $1.33 \pm 0.14^{\mathrm{a}}$ & $1.26 \pm 0.07^{\mathrm{a}}$ \\
\hline Final biomass (g.m $\left.{ }^{-2}\right)$ & & $148.7 \pm 58.7^{\mathrm{a}}$ & $389.5 \pm 40.2^{b}$ & $419.4 \pm 227.1^{\mathrm{b}}$ \\
\hline $\begin{array}{l}\text { Final combined biomass } \\
\left(\mathrm{g} \cdot \mathrm{m}^{-2}\right)\end{array}$ & $116.4 \pm 26.4^{\mathrm{a}}$ & $230.3 \pm 40.0^{\mathrm{b}}$ & $459.0 \pm 53.9^{\mathrm{c}}$ & $419.4 \pm 227.1^{\mathrm{c}}$ \\
\hline FCR & $(*)$ & $(*)$ & $2.36 \pm 0.43^{\mathrm{a}}$ & $1.75 \pm 0.25^{\mathrm{a}^{* *}}$ \\
\hline
\end{tabular}

Mean values in a same row with different superscript letters are significantly different $(\mathrm{P}<0.05)$.

$\left(^{*}\right)$ : There was not data

$(* *)$ : Value was calculated from three replicate of FM treatment since one replicate was negative weight gain 
Table 2: Water parameters in the experimental treatments throughout the experimental period. Values in parentheses are min - max. Values are means \pm SD.

\begin{tabular}{|c|c|c|c|c|c|c|}
\hline \multirow[b]{2}{*}{ Parameters } & \multirow[b]{2}{*}{$\mathrm{n}$} & \multirow[b]{2}{*}{ Unit } & \multicolumn{4}{|c|}{ Treatments } \\
\hline & & & $\begin{array}{c}\text { Shrimp } \\
\text { monoculture }\end{array}$ & $\begin{array}{l}\text { Shrimp-fish } \\
\text { polyculture }\end{array}$ & $\begin{array}{l}\text { Fish-shrimp } \\
\text { polyculture }\end{array}$ & $\begin{array}{c}\text { Fish } \\
\text { monoculture }\end{array}$ \\
\hline $\mathrm{T}(7: 30)$ & 73 & ${ }^{\circ} \mathrm{C}$ & $\begin{array}{r}23.5 \pm 0.1^{\mathrm{a}} \\
(19.6-26.9)\end{array}$ & $\begin{array}{r}23.5 \pm 0.1^{\mathrm{a}} \\
(19.6-26.9)\end{array}$ & $\begin{array}{r}23.4 \pm 0.3^{\mathrm{a}} \\
(19.4-26.8)\end{array}$ & $\begin{array}{r}23.5 \pm 0.2^{\mathrm{a}} \\
(19.5-26.9)\end{array}$ \\
\hline $\mathrm{T}(15: 00)$ & 71 & ${ }^{\circ} \mathrm{C}$ & $\begin{array}{r}27.7 \pm 0.2^{\mathrm{a}} \\
(21.5-31.2)\end{array}$ & $\begin{array}{r}27.8 \pm 0.2^{\mathrm{a}} \\
(22.4-31.3)\end{array}$ & $\begin{array}{r}27.6 \pm 0.2^{\mathrm{a}} \\
(22.2-30.9)\end{array}$ & $\begin{array}{r}27.7 \pm 0.3^{\mathrm{a}} \\
(22.2-31.3)\end{array}$ \\
\hline DO $(7: 30$ & 73 & $\mathrm{mg} \cdot \mathrm{L}^{-1}$ & $\begin{array}{c}6.2 \pm 0.4^{\mathrm{a}} \\
(4.9-7.8)\end{array}$ & $\begin{array}{c}6.2 \pm 0.1^{\mathrm{a}} \\
(5.1-7.8)\end{array}$ & $\begin{array}{c}6.3 \pm 0.3^{\mathrm{a}} \\
(5.2-7.8)\end{array}$ & $\begin{array}{c}6.2 \pm 0.4^{\mathrm{a}} \\
(5.1-8.0)\end{array}$ \\
\hline DO $(15: 00)$ & 71 & $\mathrm{mg} \cdot \mathrm{L}^{-1}$ & $\begin{array}{r}9.5 \pm 0.8^{a} \\
(6.7-11.9)\end{array}$ & $\begin{array}{r}8.7 \pm 0.4^{\mathrm{a}} \\
(7.2-11.7)\end{array}$ & $\begin{array}{r}8.9 \pm 0.3^{\mathrm{a}} \\
(7.1-12.6)\end{array}$ & $\begin{array}{r}9.0 \pm 0.2^{\mathrm{a}} \\
(6.6-11.3)\end{array}$ \\
\hline $\mathrm{pH}$ & 21 & & $7.9 \pm 0.1^{\mathrm{a}}$ & $7.9 \pm 0.0^{\mathrm{a}}$ & $7.9 \pm 0.1^{\mathrm{a}}$ & $7.9 \pm 0.0^{\mathrm{a}}$ \\
\hline Salinity & 21 & $\%$ & $36.0 \pm 0.2^{\mathrm{a}}$ & $36.0 \pm 0.0^{\mathrm{a}}$ & $36.0 \pm 0.2^{\mathrm{a}}$ & $36.0 \pm 0.1^{\mathrm{a}}$ \\
\hline Turbidity & 21 & NTU & $27.8 \pm 6.4^{\mathrm{a}}$ & $38.3 \pm 13.5^{\mathrm{a}}$ & $30.0 \pm 16.1^{\mathrm{a}}$ & $20.0 \pm 14.5^{\mathrm{a}}$ \\
\hline TSS & 6 & $\mathrm{mg} \cdot \mathrm{L}^{-1}$ & $47.0 \pm 4.7^{\mathrm{a}}$ & $58.2 \pm 35.8^{\mathrm{a}}$ & $37.3 \pm 12.2^{\mathrm{a}}$ & $31.3 \pm 5.4^{\mathrm{a}}$ \\
\hline Chlorophyll & 11 & $\mu \mathrm{g} . \mathrm{L}^{-1}$ & $68 \pm 36^{\mathrm{a}}$ & $82 \pm 37^{\mathrm{a}}$ & $58 \pm 20^{\mathrm{a}}$ & $55 \pm 11^{\mathrm{a}}$ \\
\hline Phaeopigment & 11 & $\%$ & $29 \pm 4^{\mathrm{ab}}$ & $34 \pm 3^{a}$ & $27 \pm 7^{\mathrm{b}}$ & $35 \pm 4^{\mathrm{a}}$ \\
\hline TDN & 11 & $\mu \mathrm{M}$ & $48.6 \pm 17.5^{\mathrm{a}}$ & $46.3 \pm 8.8^{\mathrm{a}}$ & $32.8 \pm 3.1^{\mathrm{a}}$ & $34.6 \pm 11.3^{\mathrm{a}}$ \\
\hline $\mathrm{DON}$ & 11 & $\mu \mathrm{M}$ & $40.1 \pm 13.9^{\mathrm{a}}$ & $36.8 \pm 5.9^{\mathrm{a}}$ & $28.5 \pm 1.2^{\mathrm{a}}$ & $31.6 \pm 9.2^{\mathrm{a}}$ \\
\hline Urea & 6 & $\mu \mathrm{M}$ & $4.9 \pm 0.2^{\mathrm{a}}$ & $6.5 \pm 4.8^{\mathrm{a}}$ & $3.8 \pm 0.3^{\mathrm{a}}$ & $2.8 \pm 0.5^{\mathrm{a}}$ \\
\hline$\left(\mathrm{NO}_{2}+\mathrm{NO}_{3}\right)-\mathrm{N}$ & 11 & $\mu \mathrm{M}$ & $0.63 \pm 0.53^{\mathrm{ab}}$ & $0.29 \pm 0.14^{\mathrm{a}}$ & $0.20 \pm 0.02^{\mathrm{a}}$ & $0.88 \pm 0.48^{\mathrm{b}}$ \\
\hline TAN & 11 & $\mu \mathrm{M}$ & $8.5 \pm 4.1^{\mathrm{a}}$ & $9.1 \pm 2.2^{\mathrm{a}}$ & $3.8 \pm 1.8^{\mathrm{b}}$ & $3.4 \pm 1.1^{\mathrm{b}}$ \\
\hline SRP & 11 & $\mu \mathrm{M}$ & $0.24 \pm 0.03^{\mathrm{a}}$ & $0.26 \pm 0.15^{\mathrm{a}}$ & $0.20 \pm 0.07^{\mathrm{a}}$ & $0.39 \pm 0.27^{\mathrm{a}}$ \\
\hline
\end{tabular}

Mean values in a same row with different superscript letters are significantly different $(\mathrm{P}<0.05)$. 
Table 3: Sediment parameters in the experimental treatments throughout the experiment. Values are means $\pm \mathrm{SD}$.

\begin{tabular}{|c|c|c|c|c|c|c|}
\hline \multirow[b]{2}{*}{ Parameters } & \multirow[b]{2}{*}{$\mathrm{n}$} & \multirow[b]{2}{*}{ Unit } & \multicolumn{4}{|c|}{ Treatments } \\
\hline & & & $\begin{array}{c}\text { Shrimp } \\
\text { monoculture }\end{array}$ & $\begin{array}{l}\text { Shrimp-fish } \\
\text { polyculture }\end{array}$ & $\begin{array}{l}\text { Fish-shrimp } \\
\text { polyculture }\end{array}$ & $\begin{array}{c}\text { Fish } \\
\text { monoculture }\end{array}$ \\
\hline $\mathrm{pH}$ & 6 & & $7.2 \pm 0.1^{\mathrm{a}}$ & $7.2 \pm 0.1^{\mathrm{a}}$ & $7.2 \pm 0.1^{\mathrm{a}}$ & $7.1 \pm 0.1^{\mathrm{a}}$ \\
\hline Sediment OM & 6 & $\%$ & $1.5 \pm 0.1^{\mathrm{a}}$ & $1.6 \pm 0.1^{\mathrm{a}}$ & $1.6 \pm 0.1^{\mathrm{a}}$ & $1.6 \pm 0.1^{\mathrm{a}}$ \\
\hline Redox potential & 5 & $\mathrm{mV}$ & $-117 \pm 8^{a}$ & $-102 \pm 14^{\mathrm{a}}$ & $-92 \pm 11^{a}$ & $-75 \pm 30^{\mathrm{a}}$ \\
\hline Chl $a$ & 6 & $\mathrm{mg} \cdot \mathrm{m}^{-2}$ & $87 \pm 25^{\mathrm{a}}$ & $88 \pm 26^{\mathrm{a}}$ & $119 \pm 29^{a}$ & $115 \pm 24^{\mathrm{a}}$ \\
\hline Phaeopigment & 6 & $\%$ & $47 \pm 5^{\mathrm{a}}$ & $50 \pm 3^{\mathrm{a}}$ & $44 \pm 6^{\mathrm{a}}$ & $49 \pm 4^{\mathrm{a}}$ \\
\hline Initial pore water SRP* & & $\mu \mathrm{M}$ & 0.02 & 0.03 & 0.03 & 0.02 \\
\hline Final pore water SRP** & & $\mu \mathrm{M}$ & $4.3 \pm 0.5^{\mathrm{a}}$ & $3.1 \pm 1.6^{\mathrm{a}}$ & $2.0 \pm 1.3^{\mathrm{a}}$ & $8.8 \pm 7.5^{\mathrm{a}}$ \\
\hline Initial pore water TAN* & & $\mu \mathrm{M}$ & 89 & 98 & 141 & 108 \\
\hline Final pore water TAN** & & $\mu \mathrm{M}$ & $886 \pm 155^{\mathrm{a}}$ & $738 \pm 228^{\mathrm{a}}$ & $413 \pm 140^{\mathrm{b}}$ & $313 \pm 149^{b}$ \\
\hline $\mathrm{SdR}$ & 5 & g. $\mathrm{m}^{-2} \cdot \mathrm{h}^{-1}$ & $107 \pm 13^{\mathrm{a}}$ & $213 \pm 130^{\mathrm{a}}$ & $155 \pm 62^{\mathrm{a}}$ & $193 \pm 199^{\mathrm{a}}$ \\
\hline Deposit OM & 5 & $\%$ & $4.6 \pm 0.4^{\mathrm{a}}$ & $4.3 \pm 0.1^{\mathrm{a}}$ & $5.2 \pm 2.4^{\mathrm{a}}$ & $4.4 \pm 1.0^{\mathrm{a}}$ \\
\hline
\end{tabular}

OM: organic matter; SdR: sedimentation rate

Mean values in a same row with different superscript letters are significantly different $(\mathrm{P}<0.05)$.

$(*)$ : The values were analysed in one replicate per treatment at the beginning.

$(* *)$ : The values are the average of all replicates per treatment at the last analyses. 


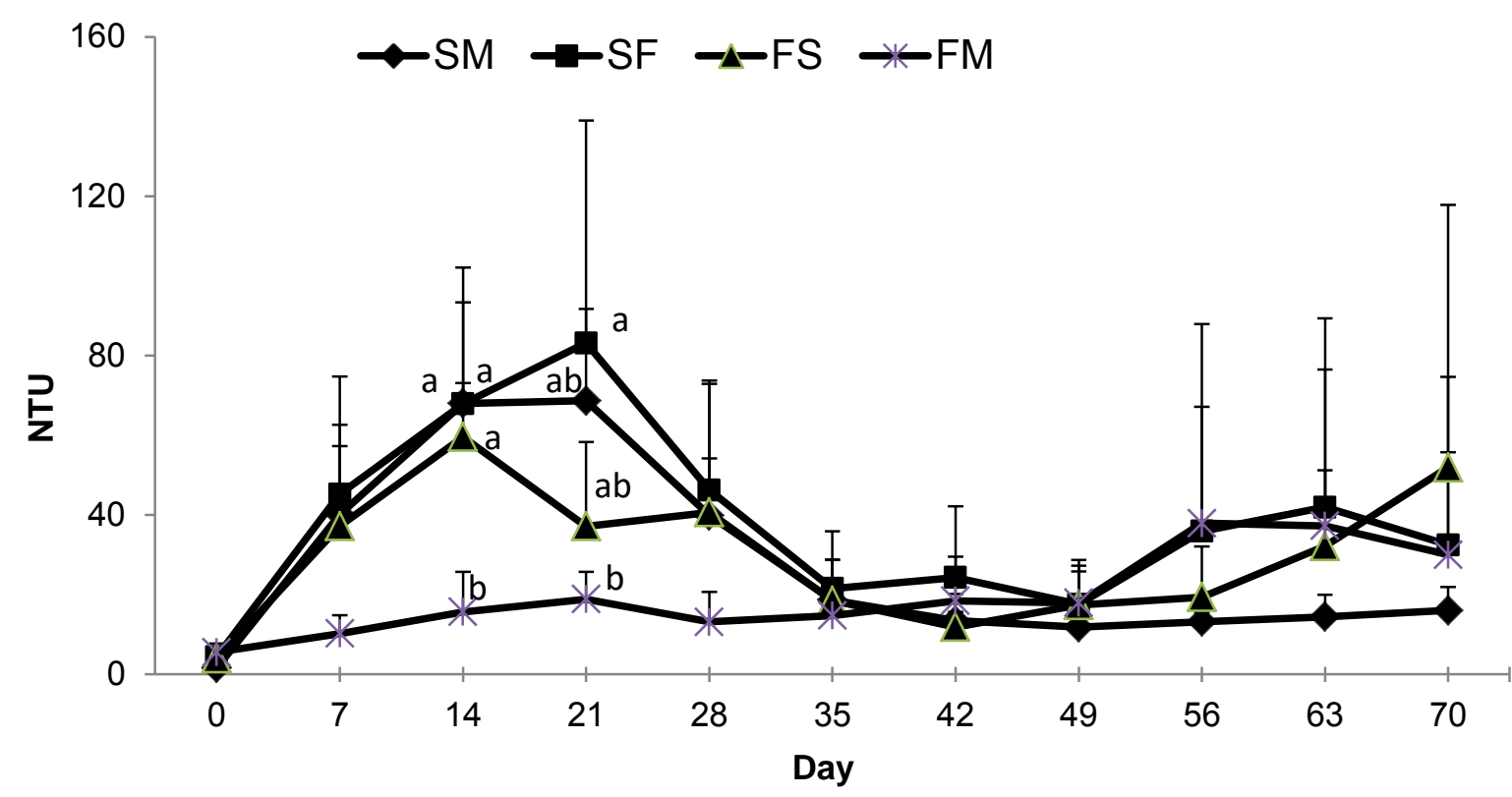

Figure 1: Temporal variations of turbidity in each treatment during the experiment. Bars present standard deviations. Values in the same day with different letters are significantly different $(\mathrm{P}<0.05)$. 

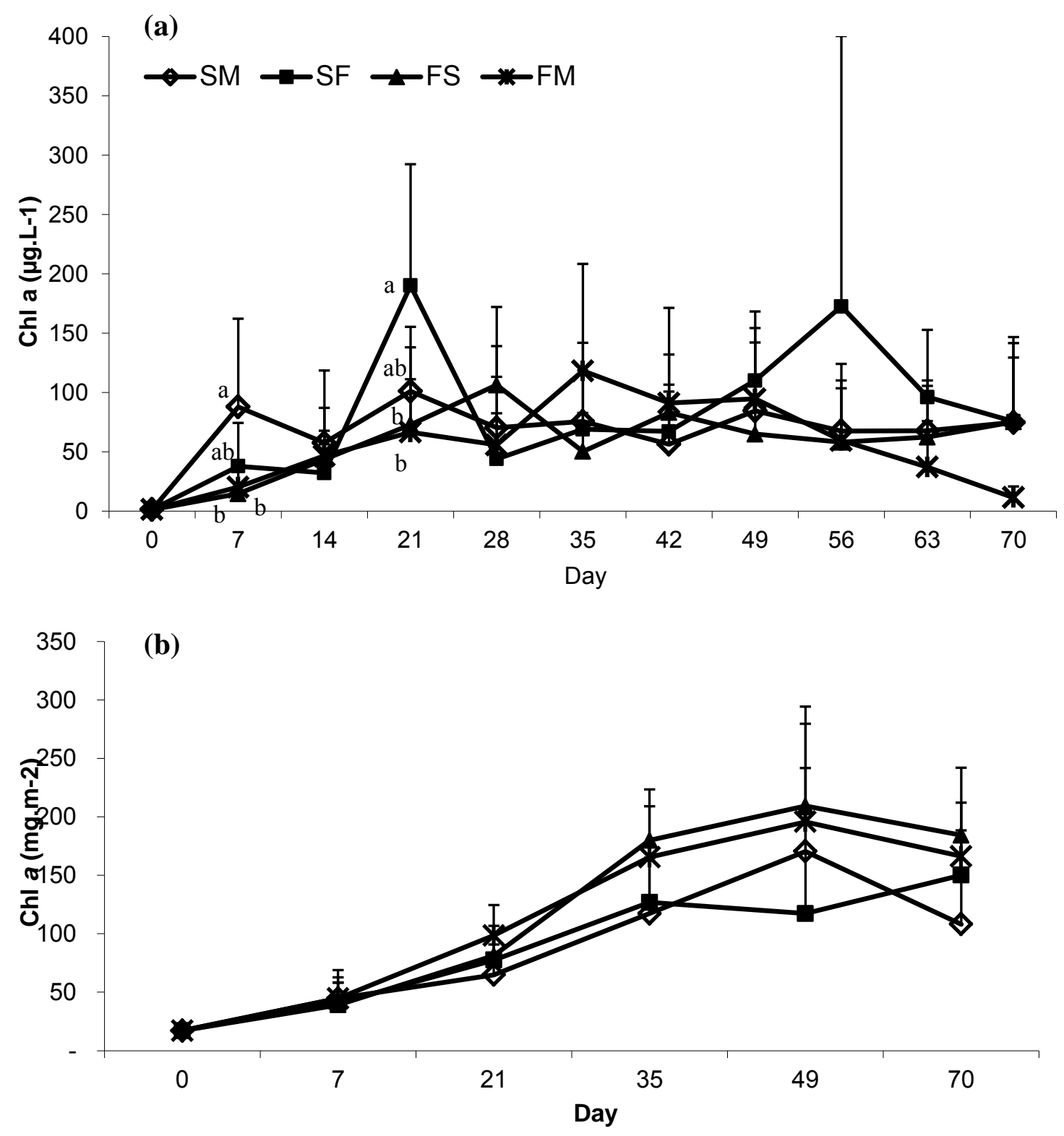

Figure 2: Temporal variations of water Chl $a$ (a) and sediment Chl $a$ (b) in each treatment throughout the experiment. Bars present standard deviations. Values in the same day with different letters are significantly different $(\mathrm{P}<0.05)$. 


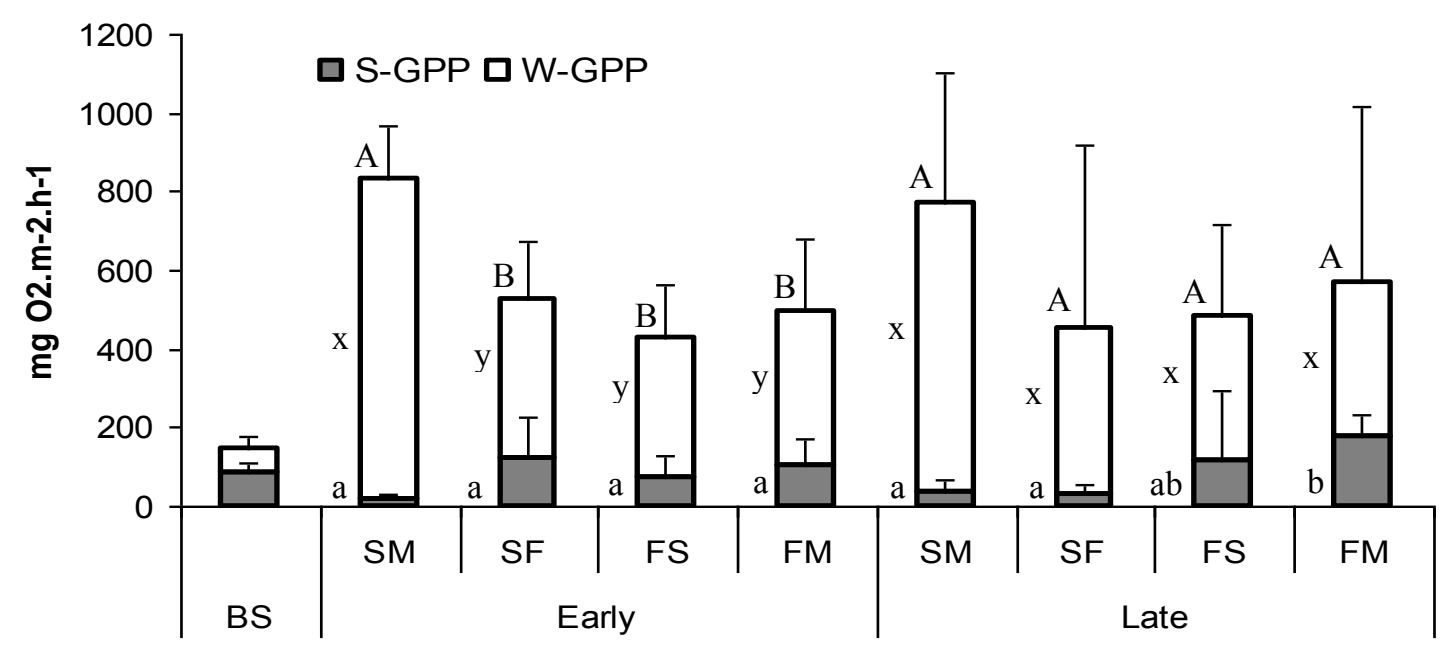

Figure 3: Water GPP (W-GPP), sediment GPP (S-GPP) and entire GPP in the whole ecosystem (W-GPP + S-GPP) in each treatment before stocking (BS), at the early and late stages of the experiment. Bars present standard deviations. In each day, values with different letters are significantly different $(\mathrm{P}<0.05)$. A, B; $\mathrm{x}, \mathrm{y}$; $\mathrm{a}, \mathrm{b}$ : represent statistical differences of entire GPP, W-GPP and S-GPP, respectively. 


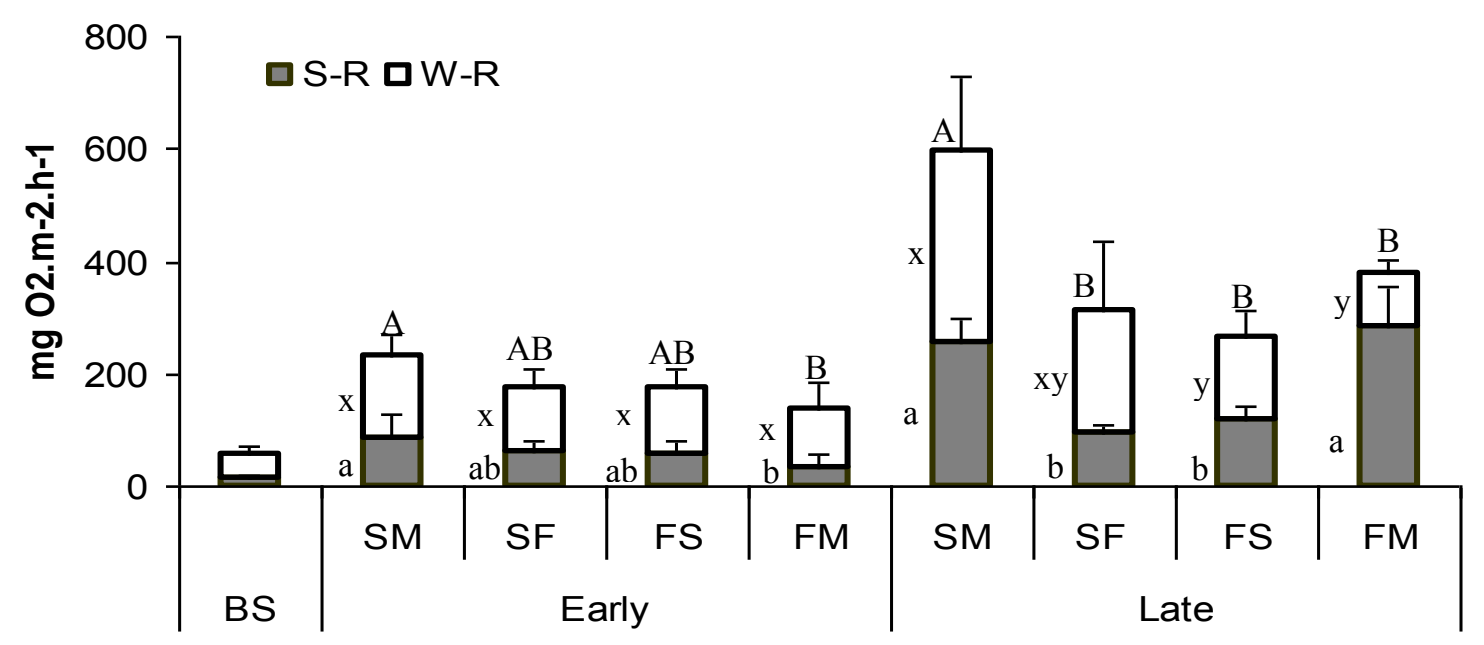

Figure 4: Respiration (R) in the water column (W-R), sediment (S-R) and the whole ecosystem $(\mathrm{W}-\mathrm{R}+\mathrm{S}-\mathrm{R})$ in each treatment before stocking (BS), at the early and late stages of the experiment. Bars present standard deviations. In each day, values with different letters are significantly different $(\mathrm{P}>0.05)$. A, B; $\mathrm{x}, \mathrm{y} ; \mathrm{a}, \mathrm{b}$ : represent statistical differences of entire $\mathrm{R} ; \mathrm{W}-\mathrm{R}$ and S-R, respectively. 


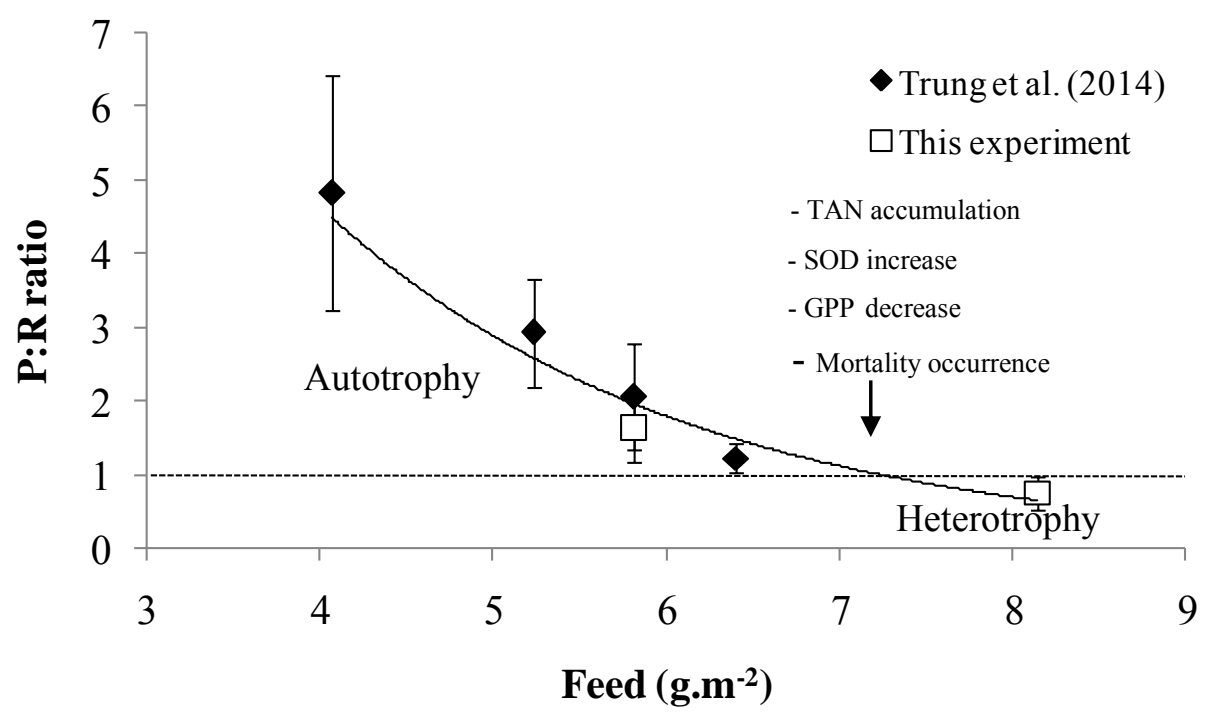

Figure 5: Relationship between trophic status of the mesocosm ecosystem and feed quantity supplied higher than $4 \mathrm{~g} \cdot \mathrm{m}^{-2}$.days ${ }^{-1}$. Diamond point: data from a previous study $(\mathrm{N}=4)$ (Luong et al., 2014), Square point: data from this study $(\mathrm{N}=8)$. Means were calculated using all the data from all the treatments whatever the experiment. 